論文

628.932 .1

\title{
線光源による壁面照明について
}

\author{
正会員三浦道 雄*
}

\section{Illumination of Vertical Wall by Linear Lightsource}

By Mitio Miura (Member)

(National Diet Library)

\begin{abstract}
To illuminate the vertical wall, if we set two long linear lightsource in front of the top and bottom lines of the wall parallel to them, the distance for the most efficient illumination will be given by the half height of the wall.
\end{abstract}

\section{1. 概説}

人工光源の5ち現在使われているものは電灯であっ て,これはその形によって点光源, 線光源, 面光源の三 つにわけることができる. 線光源は管型白熱球，けい光 放電管、スリムライン等のように，ある長さをもった線 状をなした光源であって，連設することによって任意の 長さとなし得られるものである。

博物館の展示物の中にはけい光灯をもって炤明するこ とにより，変質変色寸るのではないかという心配から，

これを好ま場合もあるといらが，けい光灯そのものは 日進月歩するもので女るから、ここではけい光放電管に よる壁面の照明について検討して見たい。

線光源であるけい光灯は, 広い面積を均等に照明しよ うする際には点光源よりる都合がよく, 光の質がやわ らかで良い感じを与え，また使用電力量が少量ですみ, 経済的でもあるから, 今後の照明は博物館といえども大 いにこれを利用する傾向になる5.けい光灯の久点であ るとされているチラッキも逐次改良されようし，また光 の質も一層よくなろらから，今後ますます盛んに使用さ れることになろう。

\section{2. 長い線光源による照庋}

既知の事実であるが話の順序として無限長光源による 照明について記そ5。今第 1 図において点 0 を紙面に 垂直に無限にのびている線光源とし，P を線光源の中心 軸 $\mathrm{O}$ から距離 $r_{0}$ を有する一点とする.今この線光源 $\mathrm{O}$ による点 $\mathrm{P}$ の照度を求めるに, 第 2 図に拈いて $\mathrm{Ox}$ を線光源とし， $\mathrm{PQ}$ を線光源 $\mathrm{O}$ と点 $\mathrm{P}$ とを含呯面

* 国立国会図書館建築部

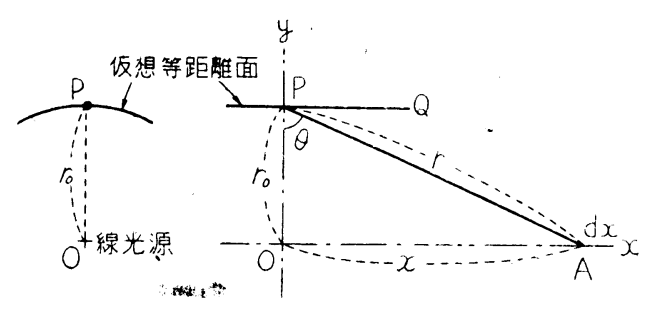

第 1 図

第 2 図

上の交線とする. 線光源の単位の長さ当り法線光度忘 $I$ とすれば，原点 $\mathrm{O}$ から $x$ の距離にある $\mathrm{A}$ 点附近の d'x なる微小長の光源の法線光度は $I d x$ であって, それを $P$ から見れば $d x$ の長さは $d x \cos \theta$ の長さに見えるか ら, $\mathrm{P}$ 点の方向えの光度は $I d x \cos \theta$ である。よって $\mathrm{P}$ 点の水平面照度 $d E$ は

$$
d E=\frac{I d x}{r^{2}} \cos ^{2} \theta
$$

$d x=r_{0} \sec ^{2} \theta d \theta, r=r_{0} \sec \theta$ であるから (1)は，

$$
d E=\frac{I}{r_{0}} \cos ^{2} \theta d \theta
$$

これを $0=-\frac{\pi}{2}$ から $0=\frac{\pi}{2}$ まで積分することに よって無限の長さの線光源 ○によるリ点の㫿度が得ら れる、すなわち

$$
\begin{aligned}
E & =\int_{-\frac{\pi}{2}}^{\pi} d E=\frac{1}{r_{0}} \int_{-\frac{\pi}{2}}^{\frac{\pi}{2}} \cos ^{2} \theta d \theta \\
& =\frac{I}{2 r_{0}}\left[\theta+\frac{1}{2} \sin 20\right]_{-\frac{\pi}{2}}^{\frac{\pi}{2}}=\frac{\pi}{2} \cdot \frac{I}{r_{0}}
\end{aligned}
$$

光度 $I$ を $(\mathrm{cd} / \mathrm{m}) 、 r_{0} を(\mathrm{~m})$ とすれば，P点の照 度 $E$ は $\frac{\pi}{2} \cdot \frac{1}{r_{0}}(1 \mathrm{x})$ であらわされる。 
線光源が 0 点の一方にのみあるとき，与なわち半無: 限长直線光源であるときには， $\mathrm{P}$ 点の照度 $E_{1 / 2}$ は (2) 式の $d E を \theta=0$ から $0=\frac{\pi}{2}$ まで積分することとなり

$$
E_{1 / 2}=\frac{\pi}{4} \cdot \frac{I}{1_{0}}
$$

で示される。

光源と壁面との距離 $r_{0}$ に比較して光源の長さが究分 長いときは，壁面の照度は光源が無限に長いものと考え て, 中央部では式（2）により，端部では式 (2')によっ て該算して差支えない。

\section{ろ. 短かい線光源による照庋}

線光源が短かいとき，例えば第3図のよ5に $I=2$ 。 である埸合には次のようになる。

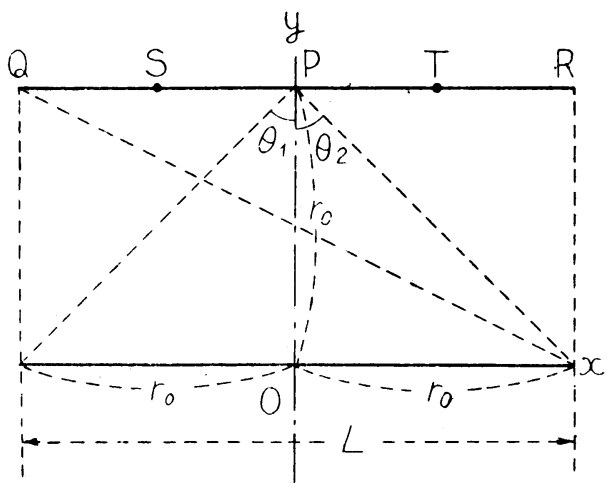

第3 図

中心点Pでは，

$$
E=2_{0}^{I}\left[\theta+\frac{1}{2} \sin 2 \theta\right]_{-\frac{\pi}{4}}^{\frac{\pi}{4}}=2.57 \frac{I}{2 r_{0}}
$$

Q 点および R 点においては,

$$
E=\frac{I}{2 r_{0}}\left(\theta+\frac{1}{2} \sin 2 \theta\right]_{0}^{\tan ^{-1} 2}=1.504 \frac{I}{2 r_{0}}
$$

$\mathrm{S}$ 点および $\mathrm{T}$ 点においては，

$$
E=\frac{I}{2{ }_{0}}\left[\theta+\frac{1}{2} \sin 20\right]_{-\tan ^{-1} \frac{1}{2}}^{\tan ^{-1} \frac{3}{2}}=2.32 \frac{I}{2 r_{0}}
$$

これを図示すれば第 4 図のようになる。これによって 見召と雨端の照度は中央のそれの $58.5 \%$ 程度となり， 中央部の半分よりは大きくなっている．光源が无分長く て無限の長さと考えて善支えない場合には，照度曲線は 基線に平行な植線で表わされ，照度は均一になる。第 4 図_上部の破線はこの照度を示す半のである。

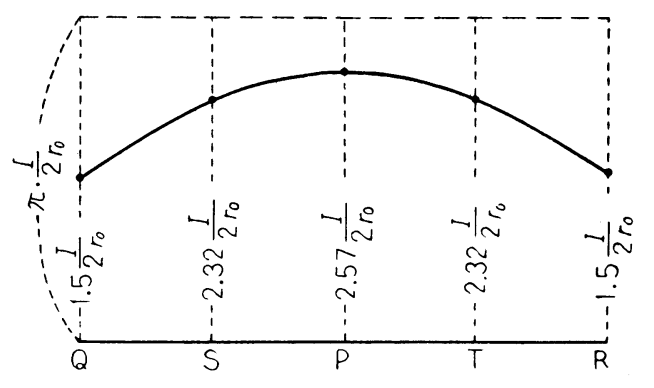

第 4 図

長い壁面に絵画などを並べて展示する場合には相当長 いけい光灯の連設ができるから，その場合には中央部で は線光源が無限に長いものとして照度を計算し，また両 端に拈いては線光源が一方にだけ無限に長い半無限長值 線光源として計算して差支えない。

このよ5な場合，中央壁面の同高の場所の照度は一定 でせる。そこで今度は壁面の高さによる照度の変化を観 察しよう。

\section{4. 線光源 1 本による壁面の照度}

第 5 図において乘直な壁面を PQ とし，その高さを $H$ とする。P の前方 $r_{0}$ の距離にある $\mathrm{O}$ 点において壁面 に平行でかつ水平な線光源があって，その長さが充分長 くそれの単位長さ当りの法線光度を $I$ とすれば, $\mathrm{P}$ 点の 照度 $E_{0}$ は式 (2) によって

$$
E_{0}=\frac{\pi}{2} \cdot \frac{I}{r_{0}}
$$

である。

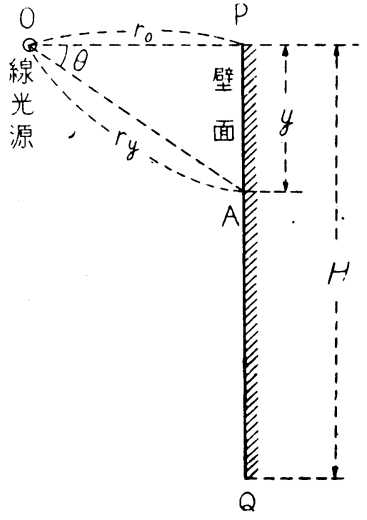

第 5 図

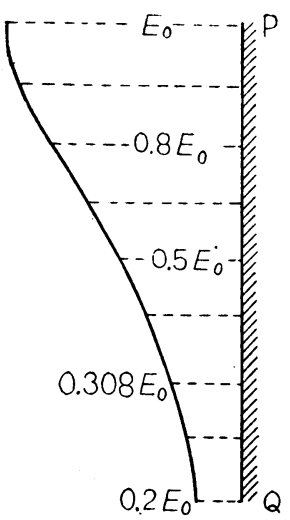

第 6 図
次にP 点から下方 $\boldsymbol{y}$ の位置にある $\mathrm{A}$ 点の照度 $E_{y}$ は。

$$
E_{y}=\frac{\pi}{2} \frac{I}{r_{y}} \cos \theta, \quad \cos \theta=\frac{r_{0}}{r_{y}} \text { こあるから, }
$$




$$
\begin{aligned}
& E_{y}=\begin{array}{c}
\pi I \\
2
\end{array} \cdot \frac{r_{0}}{r_{y}{ }^{2}}=\frac{\pi I}{2} \cdot \begin{array}{c}
r_{0}^{2} \\
r_{0}{ }^{2}+y^{2}
\end{array} \\
& =\frac{r_{0}^{2}}{r_{0}^{2}+y^{2}} E_{0}
\end{aligned}
$$

いま $H=2 r_{0}$ として $H$ の四分点について壁面の照度 を求めれば,

$$
\begin{aligned}
& y=0 \quad E=\frac{\pi I}{2 r_{0}} \\
& y=\frac{r_{0}}{2} \quad E_{\frac{r_{0}}{2}}=\frac{\pi I}{2 \frac{r_{0}}{2}} \cdot \frac{r_{0}{ }^{2}}{r_{0}{ }^{2}+\frac{r_{0}{ }^{2}}{4}}=\frac{\pi I}{2} \times 0.8 \\
& =0.8 E_{0} \\
& y=r_{0}=\frac{H}{2} \quad E r_{0}=\frac{\pi I}{2 r_{0}} \cdot \frac{r_{0}{ }^{2}}{r_{0}{ }^{2}+r_{0}{ }^{2}}=\frac{\pi I}{20} \times 0.5 \\
& =0.5 E_{0} \\
& y=\frac{3}{2} r_{0} \quad E_{\frac{3}{2} r_{0}}=\frac{\pi I}{2 r_{0}} \cdot \frac{r_{0}{ }^{2}}{r_{0}{ }^{2}+\frac{9}{4} r_{0}^{2}} \\
& =\frac{\pi I}{2 r_{0}} \times 0.308=0.308 E_{0}
\end{aligned}
$$

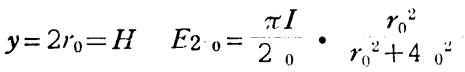

$$
\begin{aligned}
& =\frac{\pi I}{2_{0}} \times 0.2=0.2 E_{0}
\end{aligned}
$$

これを図に表はせば第6四のようになる。

\section{5. 線光源 2 本による壁面の照度}

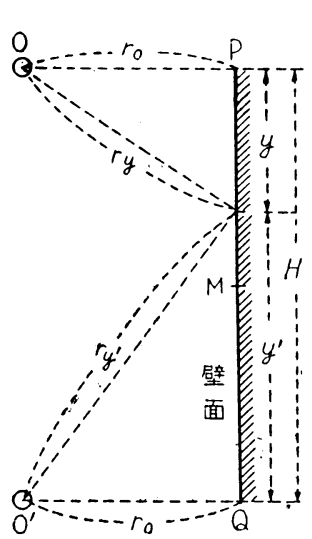

第 7 図
第 7 図に示すよ5に壁面 の上下両端 $\mathrm{P}, \mathrm{Q}$ の前方 。 の距離湶光源 $\mathrm{O}, \mathrm{O}^{\prime}$ を 取门付忛ると，A点の照度 $E_{y}$ は式（6）から

Oによるもの

$$
E_{1}=\frac{\pi I}{2 r_{0}} \cdot \frac{r_{0}^{2}}{r_{0}^{2}+\jmath^{2}}
$$

$\mathrm{O}^{\prime}$ によるもの

$$
\begin{aligned}
& E_{2}=\frac{\pi I}{2{ }_{0}} \cdot \begin{array}{c}
r_{0}{ }^{2} \\
r_{01}{ }^{2}+y^{\prime 2}
\end{array} \\
& \text { ここに } y+y^{\prime}=H
\end{aligned}
$$$$
\text { よっ }
$$

$$
E_{y}=E_{1}+E_{2}=\frac{\pi I}{2 r_{0}}\left(\begin{array}{c}
r_{0}{ }^{2} \\
r_{0}^{2}+y^{2}
\end{array}+\frac{r_{0}^{2}}{r_{0}^{2}+(H-y)^{2}}\right)
$$

\begin{tabular}{|c|c|c|c|}
\hline$y$ & $E_{y}$ & $y$ & $E_{y}$ \\
\hline 0 & $3.76 \mathrm{I} / \mathrm{H}$ & $0.6 H$ & $3.21 \mathrm{I} / \mathrm{H}$ \\
\hline $0.1 H$ & $3.825 I / H$ & $0.7 H$ & $3.37 I / H$ \\
\hline $0.2 H$ & $3.6 \quad I / H$ & $0.8 H$ & $3.6 \quad I / H$ \\
\hline $0.3 H$ & $3.37 \mathrm{I} / \mathrm{H}$ & $0.9 H$ & $3.825 I / H$ \\
\hline $0.4 H$ & $3.21 \mathrm{I} / \mathrm{H}$ & $H$ & $3.76 I / H$ \\
\hline $0.5 H$ & $3.14 \mathrm{I} / \mathrm{H}$ & & \\
\hline
\end{tabular}

$E_{y}$ のらち 極小のものを求めるために $\frac{d E}{d y}=0$ とお けば

$$
\frac{\boldsymbol{y}}{\left(n^{2}+v^{2}\right)^{2}}=\left\{\frac{H-y}{\left\{1^{2}+(H-y)^{2}\right.}\right\}^{2}
$$

が得られ， $y=H / 2$ のときに式 (8) が満足されて $\frac{d E}{d y}=0$ となり，壁面つ商さの中央において照度が最小炕るこ
とがオかる。

今 $H=2 r_{0}$, 与なわち $r_{0}=\frac{H}{2}$ とすれば，式(7)から

$$
E_{y}=\frac{\pi}{4} \cdot I H\left(\begin{array}{c}
1 \\
\frac{H^{2}}{4}+y^{2}
\end{array}+\frac{1}{\frac{H^{2}}{4}+(H-y)^{2}}\right)
$$

第 1 表

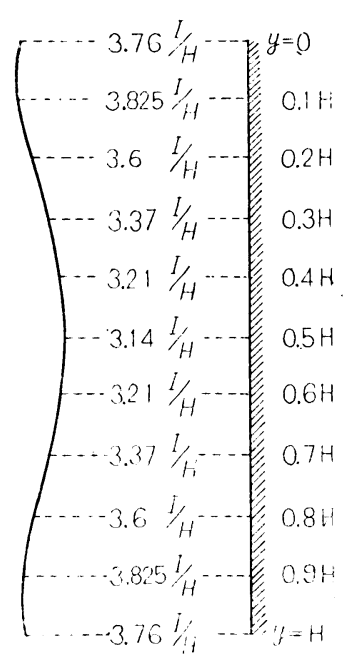

第 8 図
$H$ の十分点について $E_{y}$ の值を式 (9) から求 めれば第 1 表のよ5にな り，これを図示すれば第 8 図のようになる。これ によれば，上下両端から 少し中央よりのところ $(y \fallingdotseq 0.05 H$ および $y \fallingdotseq$ $0.95 H)$ に極大点があ

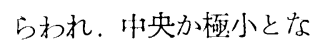
る、極大と極小との差の 制合は大略

$$
\begin{aligned}
& \frac{3.825-3.141}{3.825} \\
& \times 100=17.8 \%
\end{aligned}
$$

であって，大差はなく，

全体ほぼ均等の照度と言ってよい，

壁面の中央は観賞者の眼ふらの距漓隹が近く，梞た視線 と壁面とのな与角度が值角に近いためによく見え，上端 およひ下端は眼からの趾济倠が遠く、また視線と壁面との なす争度が小さいから見にくくなるので，照度の分有が 第8圈の上らに上下端汇行くにしたがって增大している ことはけだし合理的といってよい。

\section{6. 壁面と光源との最適距離}

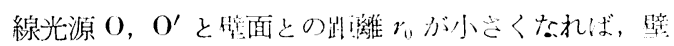
面の上下両端は非常に朋るくなるが，中央部は却って腤 くなる。また $r_{0}$ が大きくなれば壁面の照度の差は少な

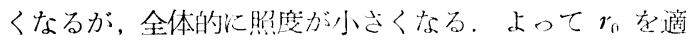

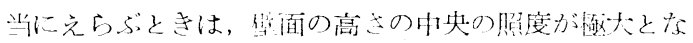

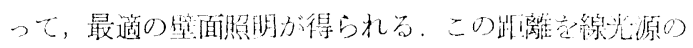


最適距離とする。

式 (7) に打いて $y=\frac{H}{2}$ と扣いて壁面の高さの中央 $M$ の照度 $E_{M}$ を求めれば,

$$
E_{M}=\frac{4 \pi I r_{0}}{4 r_{0}^{2}+H^{2}}
$$

$E_{M}$ が極大となる $r_{0}$ の值を求めるために $E_{M}$ を $r_{0}$ で微分してこれをとと拈けば，

$$
\frac{d E}{d r_{0}}=4 \pi I \frac{H^{2}-4 r_{0}^{2}}{\left(4 r_{0}^{2}+H^{2}\right)^{2}}
$$$$
\therefore H^{2}=4 r_{0}^{2} \text { または } H=2 r_{0} \text { 或いは } r_{0}=\frac{H}{2} \text {. }
$$

よって $r_{0}=\frac{H}{2}$ のときに $E_{M}$ は極大になる.

$$
\text { 式(10) に } r_{0}=\frac{H}{2} \text { を入れれば }
$$

$\max . E_{M}=\pi \cdot \frac{I}{H}$

となる.この場合の照度を示したのが第8図である。よ って, 壁面の高さの半分 (上下の両線光源間隔の半分) の距離が線光源の最適距離である.

40 W けい光放電管は長さが $1.198 \mathrm{~m}$ あって, その全 光東は $2,000 \mathrm{~lm}$ ないし $2,650 \mathrm{~lm}$ であるから，その単
位の長さ当りの法線光度は，

$$
I=180 \mathrm{~cd} \sim 238 \mathrm{~cd}
$$

となる. いま $H=4 \mathrm{~m}, I=180 \mathrm{~cd} / \mathrm{m}$ とすれば, 中央高 さの照度 $E_{M}$ は,

$$
E_{M}=\pi \frac{I}{H}=\pi \times \frac{180}{4}=143 \mathrm{~lx}
$$

また最上端および最下端の照度をそれぞれ $E_{P}, E_{Q}$ とすれば, 第 8 図の数式を使って,

$$
E_{P}=E_{Q}=3.76 \frac{I}{H}=3.76 \times \frac{180}{4}=1691 \mathrm{x}
$$

線光源の端部に拈いては $E_{M}, E_{P}, E_{Q}$ 等の值はこ れらの $1 / 2$ になることは式 (2) と式 $\left(2^{\prime}\right)$ とから容易に 理解される. また線光源が短かい場合については式(3), （4），(5）の值を参照して計算すれば，それぞれの壁面 位置の照度を求めることができる.

\section{7. 結言}

以上のように線光源による壁面照明について極めて簡 単な事実を報告したが,これについて諸賢の御比正をい ただくことができれば幸である.（昭 31-3-27 受付）
会員の声

\section{照明普及についての愚見}

\author{
正会員松 浦
}

\section{正}

戦後に打けるけい光灯のめざましい普及によって, わ が国は画期的の進歩発展を見せ，近代建築の激増に伴。 て，照明の黄金時代を招来したかの観がある。しかしこ れは極めて皮相の観であって，一般大采の生活とのつな がりを考える場合，手ばなしの楽観はでき得ないのでは ないか. 白熱の裸ランプ1灯といら状態の住居がどの程 度の割合であるか，さらに辛うじてけい光灯スタンド I 灯を所持する家庭の割合を思うとき，私達はただ照明理 論の研究に没頭し, 大建築の進んだ照明施設に満足して いるらしい学会の各先生方に, いわゆる象牙の塔を出て 大衆の実際生活に飛び込んで，どうしたらば照明をもっ と普及することができるかを検討して鿓いたいと思う。 そうすることが学会の目的の一つでもあり，学会を発展 せしめる基盤でもあるかと思われる. 勿論，学会が直接 大䀽に接触することは至難であるかもしれないが，全国 にまたがる支部と最も密接の関係にある各電力会社の照 明普及事業を積極的に応援指導することこそ，当面の急 務であると愚考して，その実施を切望する次第である。

\section{表紙説明 階段教室のけい光灯調光照明}

\section{一一東京工業大学のモデル教室——}

東京工業大学のモデル階段教室では, スライド和よび 映画による授業の時, 筆記その他の便利のため, 新型の 手動式マッダけい光灯調光器による調光照明が取り入れ られた。 40 W 天然白色ラピッドスタート型けい光ラン プ 2 灯用器具 18 灯のらち, 教壇照明用の 6 灯を除いて は $100 \%$ 0\%までの範囲で完全に調光でき，まれ器具 の中に一緒に組まれている白熱電球も必要に応じて調光 できるよらになっています。しかも教壇テーブルの引き 出しを改造して䈤め込んだ装置の同一のッマミで切換ス イッチにより,けい 光ランプ, 電球, い ずれでも自由に調光 ができます。

マッダけい光ラン プ調光装置は最も装 置自体の電力損失の 少〈, 故障箇所のな い技術的飞優れたも ので，既に多くの主 な劇場に採用され御 好評を戴いています が, その後它劇場, 集会場の照明用とし て各地からつぎつぎ と引合に接して扣り ます。

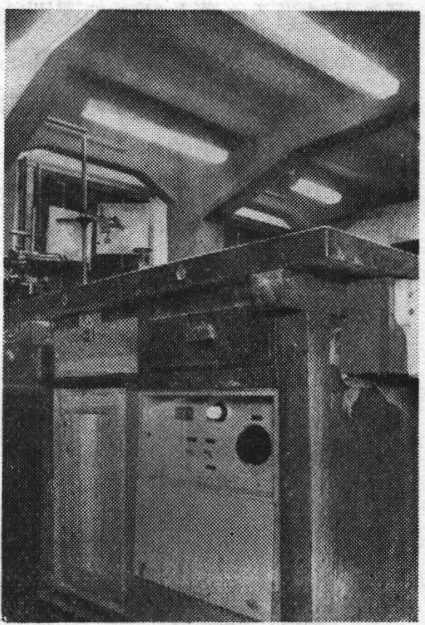

（東芝商事株式会社照明課） 